\title{
Historical Analogy: Japan's Road Toward War and Japan's Postwar Road
}

\author{
Wang Xiaoran \\ University of Macau, Macau, China
}

\author{
C. X. George Wei \\ University of Macau, Macau, China
}

\begin{abstract}
In 1931, Japan launched the Sept. 18th attack against China. Ever since, there have been many different views over the origin of Japan's road toward war, which mostly concern with Japan's land policy. This paper holds that Japan's land policy was an evolving one and it transformed along the change of its supporters and implementers during different stages. It is mostly a contention about the different strategies on Manchuria and Mongol; the northward or the southward advance faction; the orientations of the radical military occupation or the moderate economic occupation. Interestingly, the development of Japan's postwar policy toward China, especially in the recent years, resembles the evolvement of Japan's land policy in the 19th century. They both show tendency from the economic effort to the military activity.
\end{abstract}

Keywords: Japan's land policy, imperial defense strategy, Shidehara diplomacy, financial occupation

There has been much discussion that the Manchurian Incident (September 18, 1931) is the inevitable result of Japan's Mainland Policy. ${ }^{1}$ However, opinions on the nature of the Mainland Policy are divided. Basically, there are three types: Firstly, the Mainland Policy includes military expansion and territory annexations, with the process of Korea, Ryukyu, Taiwan, Northeast China and the whole China, Siberia, Indochina Peninsula and the Southeast Asia; ${ }^{2}$ secondly, the Mainland Policy is a kind of economic behavior, but under the background of territory annexation; ${ }^{3}$ thirdly, with the military and economic expansion, the Mainland Policy had become an important part of the Asia-Pacific strategy of Japan which was not only a policy for the neighbors but also a response to Europe and the United States. ${ }^{4}$

Consistent with above views, this paper also agrees that the Manchurian Incident is the inevitable result of the Mainland Policy. And, the scope of the Mainland Policy includes not only the East Asian continent. The policy in East Asia would influence Japan's Pacific Policy, therefore also affects Japan's international relations with Europe and the United States. But beyond that, in general, the Mainland Policy was also gradually formed. In different stages, the content, supporters, and executives of that policy were changing. It is also a policy of many factors in combination. Those factors include the debate and harmonic of Ministry of the Navy and

Wang Xiaoran, Ph.D. Candidate, Student, Department of History, FSS, University of Macau.

C. X. George Wei, Ph.D., Professor, Department of History, FSS, University of Macau.

Correspondence concerning this article should be addressed to Wang Xiaoran.

1 Xiong Peibiao, Modern Japanese hegemony strategy. Beijing: Social Sciences Press, 2005, pp. 28-64.

2 Huang Dingtian, “On Japan's Continental Policy and Russia's Far East Policy”, Northeast Asia Forum, 2006, vol. 14, no. 4, p. 7.

3 Li Liangyu, "Invasion and Annexation of Ryukyu Modern Formation of Japan's Continental Policy", Fuyang College Journals, 1999, vol. 4, pp. 97-103.

${ }^{4}$ Zang Yunku, Modern Sino-Japanese War and Japan’s China Policy Beijing. Beijing: Publication of Social Science, 2006, p. 3. 
Ministry of the Army, northward and southward development, and the military circles and politicians; different colonial policies to Manchuria, Mongolia, and East Asia; the changing political situation of Asia-Pacific. This process shows both the need for survival and development of Japan, and Japan's ambition for leadership in East Asian since the Meiji Restoration. In fact, this kind of demand and ambitions is always there even in different historical periods and situations. From the economic and military strategy of the post-war Japan, we can also see the continuity.

\section{The Synthetic Action in the Process of the Mainland Policy}

Although there are different viewpoints about the formation of the Mainland Policy, many scholars support the view that Japan's National Defense Policy after the first Sino-Japanese War formed the root of the Mainland Policy. This paper argues that, although theories about the Mainland Policy had been mentioned in other pamphlets and memorials to the throne, ${ }^{5}$ Japan's Empire Defense Policy in 1907, ${ }^{6}$ as a basic principle of Japan's national defense tactic, covers a comparatively comprehensive national strategy and target of that time. For example, the Empire Defense Policy gives ideas about taking what kind of national policy, the strategic consideration to China and the West World, achieving what kind of political and military achievements, etc. ${ }^{7}$ It is a long-term policy about Japan to East Asia and even the Asia-Pacific region, and was released in the name of the Empire. The emerging process of the Empire Defense Policy has fully shown the influence of various factors on the formation of the Mainland Policy.

\section{The Empire Defense Policy With the Army and Navy}

After the first Sino-Japanese War, as the navy and army were struggling for military dominance, the navy opposed the idea of further development to mainland, especially the idea of the Mainland Policy and the national defense strategy of occupying China as defense line.

However, the supporting point for the navy to fight military dominance was the significant victory of Japanese navy in the first Sino-Japanese War. While, one of the most important results of the victory of navy was the occupation of Taiwan and North Korea. That just became the basic factor of Offensive Defense Strategy by the army, and ran contrary to the purpose of the navy as "sweeping enemies into open sea". Even if putting Taiwan as base to South Pacific Ocean, in order to guarantee Taiwan, Japan should first take the thinking mode of the Mainland Policy and control Fujian.

\section{The Empire Defense Policy and Japan's Economic Policy in the Mainland Policy}

One of the important reasons for Empire Defense Policy of 1907 to pay more attention on the mainland even to become the fundamental principle of the Mainland Policy, was that Japanese economy had been facing a transformation. Japanese economy needed more support of the raw materials and market of East Asia.

In his The Studies on Problem of Japan's Textiles and Raw Cotton, Nawa Touitsu put forward the three stages of Japan's economy: When Japan expanding through invaded China, it in fact dominated the third link (China), and got the purpose to break through the trade restriction of the United Sates (the first link) and British (the second link). Nawa Touitsu gave the concept of "three links" to show the problems of Japanese aggression

\footnotetext{
5 The first visible idea of the Mainland Policy can be seen in the Administrative Policy of Yamagata Aritomo in 1890.

6 The first Defense Policy of Japan after the first Sino-Japanese War.

7 Since then, Japan's Defense Policy was modified for several times. Only by the Manchurian Incident in 1931, there had been two times of changes (1918 and 1923 respectively), every time reflects the change of various elements.
} 
in the 1930s. While, Ishii Kanji thought that the "three links" of Nawa, had already appeared in 1907.8 Therefore, at that time, to control the market of China, had become Japan's economic consideration.

When the army offered the Empire Defense Policy of 1907, they considered more on military offensive. But it also thought about the important role of East Asia especially China to Japan's economic development. Tanaka Giichi had already talked about the economic situation of different areas of China and the important of them to Japan in his Tanaka Draft. Tanaka Draft is also called as Draft of Empire Defense Policy. From this point of view, the Mainland Policy of the army was helpful for Japan's economic development in China and encouraged the investment of Japanese capital to the Mainland.

\section{Mainland Financial Policy and the Failure}

Although took the Empire Defense Policy as its fundamental principle, the Mainland Policy was a continuously developed policy. It was affected by various factors. And, there would be different strategy. Even in the same period, the military, civilian, and financial circles would see different ideas or theories.

For the Mainland Policy, at the very beginning, it was the economic strategy, instead of military or political ones, that was carried out by Japan. That economic strategy was called "Outline of Policies and Facilities for Sino-Japan Goodwill and Economic Support". The climax of that strategy was Nishihara Loans. It ended in 1918. The end of that campaign of Nishihara Loans also announced the failure of the Mainland Financial Policy.

\section{Practice and Speech of the Financial Expansion to East Asia Continent}

Among various kinds of viewpoints on Sino-Japanese economic cooperation, the idea of financial proposals had been put forward for many times.

In the 1910s, the Japanese financial circles did not only appear obvious tendencies to expand in China by financial means, but also paid more attention to the Chinese revolution to overthrow the monarchy. As the government was considering to get involved in the revolution, those political merchants who controlled various financial and business resources, and had strongly political back ground, began to contact with the representative figure of China's revolutionary party. Through the "cooperation" with them, the Japanese political merchants had set up corporations under the name of Chinese company but invested by Japan.

"China Kogyo Kabushiki Kaisha" (Industrial Co., Ltd in China) was put forward in this period. That was a cooperative project directly involved by Sun Yat-sen. The contract of association is as following:

The best way to further consolidate the two big countries of close relationship in East Asia, increase that companionship as lips and auxiliary, and make sure the guide and support to each other, is to strengthen the economic chain. Thus, the powerful industrialists of the two states get together to seek the way of East Asia in the coming one hundred years, and decide to set up the Sino-Japanese jointed industrial Co., Ltd in China.

The corporation and shareholders include nearly all of the leaders of political merchants in Japan.

\section{Mainland Financial Policy-To Put Forward the Economic Support Scheme}

The idea of Industrial Co., Ltd in China was finally failed due to the replacement of Nanjing National Government with Yan Shih-kai Government in Bejing. The Japanese government then secretly signed Article 21 with Yan Shih-kai. And, tried to control the government, military power, and economy of China. That conspiracy was likewise failed. However, the Japanese government had been deeply influenced and reminded

${ }^{8}$ Ishii Kanji, Huang Shaoheng translated, Economic History of Japan. Taibei: Wu-Nan Book Company Ltd, 2008, p. 228. 
by the former ideas of financial circle. Thus, Japan continued to put the economic policy (especially the financial policy) into practice.

When Terauchi Masatake became the Prime Minister, Japan began to increase investment in China. The aide and staff of Terauchi Masatake, named Nishihara, believed "if occupy China ...need to take the biggest risk of the fate of the nation... but the policy of assimilation amity is completely goodwill". ${ }^{9}$ Influenced by this viewpoint, Nishihara travelled between two countries to boost the investment and loan from Japan to China, as much as it can be, even without guarantee. Cooperating with him, on June 27, 1918, the Bureau of Finance put forward "Goodwill and Policies and the Outline of Economic Support between Japan and China". That paper emphatically discusses the financial policy to China, including loans, duties, and related control measures of banking institutions. It is a comprehensive measure to introduce Continental Policy by financial means. Nearly all of the big financial institutes of Japan joined in this program. The program also welcomed those small, non-governmental economic organizations. This program is called Nishihara Loans.

\section{The Failure of Nishihara Loans and the Giving up of Mainland Financial Policy}

Japanese merchants and financiers had been interested in China for a very long time. Financially, their opinion influenced the government. In 1918, after decades of endeavor of Nishihara, Japan implied a comprehensive financial strategy to China. Through that strategy, the Japanese government called for the investment of Japanese (even the colonies') banks in China. It also resolved the conflict of government and financial leaders about bank-building in China. In that time, Japanese people believed that the Mainland Policy, which was originally set up by military powers for army expansion, would achieve its aim by the "omnipotent Yen". But the Japanese might be too optimistic.

During Nishihara Loans, the financial institutions of Japan and its colonies became the biggest creditor of Beijing government at that time (Duan Qirui government). Some money was even provided by the Japanese government in the name of these financial institutions. On the surface, the policy indeed met expectation of the Japanese government "to obtain economic rights as the goal of colonial bank", as the Duan Qiri government mortgaged the right of railway, mining, deforestation, and other economic rights. But the fact was not like what the Japanese government had hoped. The Duan Qiri government did not use this money to develop the economy. The original loans for railway and bank building were mostly used as military spending and to pay back external debt of other countries. Japanese investors cannot get returns in the short term. Domestic public opinion gradually became distrustful to the economic cooperation policy. To 1925, when the National Government of China was established, they refused to pay the money and interest of "foreign debt borrowed by President of bribery under the Beijing government". Domestic opinions of Japan began to accuse the loan policy as traitorous act.

Eventually, the loan could not recover and Nishihara was treated as a traitor as Japanese people. The Mainland Financial Policy failed. Japan turned to political interference to China especially to Manchuria and Mongolia. But Japan did not turned to hard way of the Mainland Policy immediately.

\section{The Mainland Policy of Japan in the 1920s and the World Situation}

In 1920s, Japan experienced a period of the Mild Mainland Policy to the Hard Mainland Policy. The

\footnotetext{
9 Japanese Ministry of Foreign Affairs, Japan's Foreign Chronology and Primary Documents. Tokyo: Hara Shobo, 1966, pp. 391, 425.
} 
representative of mild method is Shidehara Kijuro. Shidehara Kijuro accepted the treaty of the Washington Conference in 1921 in the position of the foreign minister of Japan (1924-1927). He took the concerted diplomatic policy. Thus, the Mainland Policy was also operated in the name of "non-interference", "economic cooperation", etc. However, there was more and more opposition to the Mild Mainland Policy and diplomatic strategy of Shidehara Kijuro. Then, after two years of hard diplomacy during the cabinet of Tanaka Giichi (1927.4-1929.7), the cabinet of OsachiHamaguchi attempted to restore the Shidehara diplomacy but failed. The Mainland Policy of Japan turned to the hard way. And finally, came the Manchurian Incident on September 18, 1931.

\section{The International Situation and Diplomatic Policy of Japan}

After the end of the First World War, America and Japan had a competition in the Asia-Pacific region. For the American, the Paris Peace Conference did not realize their basic idea of post-war diplomacy. For the Japanese, theydid not reach the original goalofoccupying more colonies from China. But Japan"forced China to strengthen and expand the privileged status of the Japanese in Manchuria and Mongolia. And, China agreed Japan to establish a system for the privilege of similar Manchuria in Shandong province. Japan was also agreed to establish the special position in Fujian province". ${ }^{10}$

However, in the Washington Conference of 1921, the rights and interests of Japan on the Continent of East Asia and the Pacific, was limited in further. Through the Four-Power Pact, the United States greatly limited the Anglo-Japanese Alliance; the Naval Arms Limitation Treaty, not only limited the development of Japan's naval forces, but also admitted some of the rights and interests of Japan in the Far East Pacific; the Nine-Power Treaty stressed on the issue of "open door policy" in China. Japan signed these treaties, and "temporarily abandoned the brutal force expansion policy". ${ }^{11}$

As Japanese economy was depended on the United States, that choice was good for the Japanese economy. To some extent, the Washington Conference was a coordination of the Open Door Policy of America and the Mainland Policy of Japan. Shidehara Kijūrō, who would carry out moderated foreign policy in Japan, was the ambassador to the United States at that time. He signed those treaties and achieved temporary compromise of the two countries.

But, Japan still had contradictions with western countries on the East Asia and the Pacific Ocean. Some domestic public opinions had always objected the result of the Washington Conference. Even in the rise stage of Shidehara Diplomacy, there werecalls for "revenge" to the United States in Japan. In 1927, the negotiation in the Naval Disarmament Conference in Geneva was broken down. There was no substantial agreement. Global economic crisis in 1929-1933, had changed the overseas market environment of Japan, and posed a threat to the Japanese capitalism. The demand for the Chinese market was extremely increased. In 1930, Japan and the United States disputed nearly two months in the Naval Disarmament Conference in London. Even when the Prime Minister Hamaguchi Osachi (he supported the Shidehara Diplomacy) signed the treaties, the final approval work in Japan was still widely blocked.

All of those implied a great crisis hiding behind the compromise of Japan and the United States in East Asia in the 1920s.

\footnotetext{
${ }^{10}$ Jiang Xiangze, "China and the Washington Conference", Series Editor Committee of Sino-US Relations, Proceedings of Sino-American Relations (first series). Chongqing: Chongqing Publishing House, 1985, pp. 272-273.

${ }^{11}$ Ma Long, "US-Japan Peace and Conflict under the System of Washington", Journal of Hubei University of Education, 2001, vol. $28,65-67$.
} 


\section{Shidehara Diplomacy and Failure of the Mild Mainland Policy}

As the failure of the Nishihara Loans and the end of the First World War, Japan faced a totally new situation in the world. See from the result of the Washington Conference, we can get that in the beginning of the 1920s, Japan had trended to choose the "international coordination" in foreign affairs. The Shidehara Diplomacy during 1924 to 1927, proposed policies of "reasonable", "international coordination", "economic doctrine", "the interior not interventionism" as the diplomatic principles. ${ }^{12}$ Although, in the name of the so-called "interior non-interference", Japan still fully controlled Manchu and Mongolia, the Mainland Policy of Japan was a mild one in general.

However, the mild policy of Shidehara Diplomacy did neither ease relations between China and Japan, nor tempered the internal contradictions of Japan.

In China, since the end of World War I, more and more people called for "the abolition of the unequal treaties" (to restore Chinese national sovereignty). While, when Shidehara emphasized the "reasonable rights" in China, he actually want to maintain the privilege in Mongolian and Manchu. ${ }^{13}$ Thus, although the Shidehara Diplomacy adopted the mild method of the Mainland Policy, there would be inevitable conflict between Japanese policy and Chinese movement to restore the national sovereignty.

In Japan, since the beginning of Shidehara Diplomacy, the army and right-wing party had always been opposed to this diplomatic strategy. The movement in China also stimulated the domestic sentiment in Japan.

In March 1927, a severe financial crisis broke out in Japan. The Shidehara Diplomacy was denounced as "soft diplomacy". ${ }^{14}$ People blamed the crisis to Japanese government which supported the Shidehara Diplomacy. In April 1927, Reijiro Wakatsuki resigned and Tanaka Giichibecame the new Prime Minster. Although Tanaka Cabinet was quickly ended for resigning of Tanaka Giichi on July 2, 1929, the doubt and denying to the Shidehara Diplomacy got to climax during that time.

On April 19 and May 28 of 1927, the Kwantung army invaded Shandong Province for two times and manufactured the Jinan Massacre. On June 4, 1927, this army created the Huanggu Village Incident and attempted to occupy the Northeast China. From June 27 to July 7, in the Eastern Conference, the Tanaka cabinet identified the Outline of China Policy: "when there are threats to our country, regardless of pattern", Japan would take up defensive positions. Internationally, the Tanaka cabinet dismissed the principle of "Manchu and Mongolia as part of China" in the Washington Conference and actively promoted Separation Policy. Japan had gradually enforced the hard Mainland Policy.

The achievements of Shidehara Diplomacy was almost totally disputed then. Although Hamaguchi Osachi replaced Tanaka Giichi and supported the Shidehara Diplomacy, that diplomacy had less and less influence in Japan.

After the assassinating of Prime Minster Hamaguchi Osachi on November 14, 1930, many other supporters of the Shidehara Diplomacy was also kicked in Japan. More and More Japanese people began to support the hard Mainland Policy. On September 18, 1931, Japan launched the Mukden Incident. That is the "first severe challenge of Japan to Washington system". 15

\footnotetext{
12 OohataTokusiro, Diplomatic History of Japan. Tokyo: Seibundoh, 1993, p. 120.

13 OohataTokusiro, Diplomatic History of Japan. Tokyo: Seibundoh, 1993, p. 124.

14 OohataTokusiro, Diplomatic History of Japan. Tokyo: Seibundoh, 1993, p. 125.

15 Liu Yonghua, "The Manchuria Political Stability and Diplomatic in Shidehara Period", Journal of Foreign Study, 2015, vol. 4, p. 35 .
} 
Till then, Japan's Mainland Policy, had gone through the Financial Mainland Policy and the Mild Mainland Policy, and began to turn to the Hard Mainland Policy which means the war.

\section{The Change and Continuity of Japan's Policy to China Postwar}

The geographical position of Japan determines the connection of Japan and East Asia continent. That also makes it impossible for Japan to give up the continent ofEast Asia. The policy of postwar Japan to China and the political adjustment of Japan to China also show that.

\section{"Distinction Between Politics and Economic" and "Economy Go Ahead"}

The policy of "Distinction between Politics and Economic" of Japan to China, was originated in the early Cold War. Japan, on the one hand, recognized the government of Chiang Kai-shek as China's legal regime and kept away the mainland China politically; on the other hand, saw the important role of Chinese mainland to the economy of Japan and considered the mainland as a potential market. Also, in the early cold war, America's China policy was to open China as the market of Japan. That had an important influence on Japan's China policy of that time.

After the end of the cold war, especially as China's rapid economic growth, Japan's policy toward China became political protection on the one hand, and emphasizing the importance of economic cooperation on the other hand. At this point, Japan had made a choice similar to the United States. It was also "a subjective choice" of Japan "to seek normal state method and gain international advantages". 16

While, the post-war Japan's China policy, although took the policy of "Distinction between Politics and Economic", has a similarity to the policy of before and during the war. Japan wants to become a leader in Asia. Thus, East Asia, especially China, has important significance to Japan. That determines Japan will pay close attention to the economic, political and military aspects of China, and take different strategies to China according to the international situation. The economy goes ahead as the guide, when "economy weakened, the military growth" ${ }^{17}$ Of course, at the same time as the military growth, Japan still emphasizes oneconomic exchanges. That is also a kind of "Distinction between Politics and Economic".

As early as the 1960s, although there were no normal diplomatic relations between China and Japan, some companies in Japan, had begun to urge the government to relax its trade with China. That greatly contributed to the normalization of diplomatic relations between two countries in 1972. Tanaka Kakuei's visit to China, got great support of financial circles. ${ }^{18}$

Since then, taking economy as the forerunner to enter into the Chinese market, had become Japan's first choice. And, during that period, Japan's economy was in a rising and Japan had gradually become the world's second-largest economy. Its national strength and international influence had enhanced unprecedented. These factors brought strengthen confidence to Japan. It hoped to impose influence in East Asia relying on strong economic strength. Prompted by expectation to a big market in China, andthe self-confidence and superiority, Japan put on policy of friendly cooperation with China. In that period, positive dialogue was also caused by the feeling of "guilt". Besides, Japan has always followed the United States. Thus, it was also influenced by

\footnotetext{
${ }^{16}$ Lvping, "The Separation between Japanese Economic Policy and Political Policy to China under the Trilateral Structure of PRC-USA-Japan", Journal of Liaoning University, 2014, vol. 42, pp. 172-177.

${ }^{17}$ Lvping, "The Separation between Japanese Economic Policy and Political Policy to China under the Trilateral Structure of PRC-USA-Japan”, Journal of Liaoning University, 2014, vol. 42, p. 175.

${ }_{18}$ LiQiao, "Japan's China Policy at the Beginning of the 21st Century and Its Impact on Sino-Japan Relations", Journal of Binzhou Vocational College, 2007, Aug. vol. 4, pp. 13-17.
} 
Nixon's visit to China and the establishment of diplomatic ties between China and America.

The post-war Japanese economy developed rapidly. To the middle 1980s, Japan's foreign trade and investment had increased sharply. By extending its economic influence and seeking closer links with East Asia, especially China, Japan had boosted its political status in Asia, which even alarmed Washington. The close relationship between Japan and the US was once loose. ${ }^{19}$ Only after ten years, when Japan did not emerge as Asia's champion in the late 1990s, the two countries strengthened the bilateral relations again.

\section{Failure of the Economic Hegemony and Strengthening of Military Strategy}

During the 1990 s and especially in the $21^{\text {st }}$ century, with the conflict in some diplomatic issues, the relationship between China and Japan began to fall into the "freezing point" ${ }^{20}$ One of the important reasons is that the Japanese influence in Asia did not meet expectations. While, with the development of China, and the enhancement of China's comprehensive strength, Japan emphasized more on the Chinese threat in policy toward China.

In Japan, because of the stagnation in economic expansion, the credibility of Japan was affected in Asia. Besides, Japan faced the problem in domestic politics. As the Liberal Party was defeated in the 1993 election, Japan was forced to pay more attention on domestic affairs. Due to the North Korean nuclear problem around 1995, and Chinese military exercises in the Taiwan Strait in 1996, Japan began to reassess the close relations in Asia. For growing doubts to China's long-term plan, Japan calculated its nascent Asian plan, and strengthened ties with the United States. ${ }^{21}$

From 2001 to 2001, under the administration of Prime Minister Junichiro Koizumi, Japan "fell into political and economic confusion". Politically, the prime minister changed replaced. Economically, Japan's economy had stalled in 2007, before the global financial crisis. ${ }^{22}$

While, as there was a policy of "Distinction between Politics and Economic", the Sino-Japanese trade relations was not interrupted. From 2001 to 2004, the two sides' trade not only did not decline, but also nearly doubled from $\$ 87.75$ billion to $\$ 167.89$ billion. Even after declaring "nationalization of Diaoyu islands", which brought very bad influence on trade between the two countries, Japan still emphasized on maintaining a positive attitude to China trade relations. ${ }^{23}$

For the sake of Japan's economic development and economic environment, the first cabinet of Abe visited Beijing for the so-called "ice-breaking". At that time, the Abe cabinet basically adopted a detente with China. For example, he tried to put forward a "mutually beneficial relationship based on common strategic interests" between Japan and China. When the election came in 2006, he adopted fuzzy strategy to the original claims such as visiting the Yasukuni Shrine. After secret visit to the Yasukuni Shrine in April 2006, Abe no longer clearly insisted the former presentation which argued that the prime minister should visit the Yasukuni Shrine. He said that because diplomatic problems was involved, he would not release that if he had ever visited and

\footnotetext{
19 Christopher B. Johnstone, "Paradigms Lost: Japan's Asia Policy in a Time of Growing Chinese Power", Contemporary Southeast Asia, 1999, vol. 21, no. 3, p. 366.

${ }^{20}$ Especially in the Koizumi administration.

${ }^{21}$ Christopher B. Johnstone, "Paradigms Lost: Japan's Asia Policy in a Time of Growing Chinese Power", Contemporary Southeast Asia, 1999, vol. 21, no. 3, pp. 365-385.

${ }_{22}$ Nakanishi, Hiroshi, "Military Cooperation and Territorial Disputes: The Changing Face of Japan's Security Policy". In Japan: The Precarious Future, edited by Frank Baldwin and Anne Allison. New York: New York University Press, 2015, p. 236.

${ }^{23} \mathrm{Li}$ Qiao, "Japan's China Policy at the Beginning of the 21st Century and Its Impact on Sino-Japan Relations", Journal of Binzhou Vocational College, 2007, Aug. vol. 4. pp. 13-17.
} 
would visit. ${ }^{24}$ On August 3, 2006, He attended the second session of the BBS for "Beijing-Tokyo" Sino-Japanese relations and said that "Sino-Japan relations is one of the most important bilateral relationship", "Japan and China cannot let political issues to affect the relationship between the economy of two countries". 25 But on the aspects of politics, Abe's attitude to China was completely inconsistent with economic attitude. He insisted on "hard policies". ${ }^{26}$

The view above is a typical thought of "Distinction between Politics and Economic". As the former policy of economic hegemony had failed, Japan emphasized more on to strengthen the military power. Thus, the strategy for "Distinction between Politics and Economic" was also changed. On the one hand, it called for economic cooperation to maintain its overseas trade. On the other hand, it emphasized China's military threat and the "necessity" for Japan to strengthen military force.

In terms of military, Japan increased focus on China's military modernization in the Defense White Paper. Since 2005, Japan had deleted the consistent evaluation for Chinese military as "insufficient overall mobility and vitality" in Defense White Paper. The 2005 in Defense White Paper emphasizes the construction of Chinese Special Forces and the Quick Reaction Force. ${ }^{27}$ The 2007 Defense White Paper emphasizes the improvement of China's aviation electronic warfare capabilities and intelligence gathering ability, mentions that China is trying to construct in the command ability and the ability to ship attack. ${ }^{28}$ The 2010 Defense White Paper compares the Chinese military spending in ten years, thinks that China's military spending increased substantially in ten years. That is the important basis of "China threat" theory. It "reviews" the "security vacuum" state in Japan including the Diaoyu Islands. ${ }^{29}$ The 2012 Defense White Paper believes that the Chinese navy had appeared in the Pacific normally. China had become a concern of the Asia-Pacific region. ${ }^{30}$

\section{Amending the Constitution and the Needs of the War}

Since taking office again in 2012, Abe had adjusted to the domestic economy, made deregulation plan and the inflation target of $2 \%$. He also gave an economic stimulus plan of $\$ 102$ billion. "Abeconomics" made the Nikkei Index rose faster. However, Japan's influence on Asia cannot achieve by short-term economic effect of the "Abeconomics". As the discussion about threaten from China, Asian military tensions and Japanese bearing no power in Asia in those Defense White Paper, Abe proposed political demands as "ending the postwar system", "Japan's real independence", etc. ${ }^{31}$ He finally put forward the demands of "rewriting the constitution". The ultimate aim of that is to get rid of the original system of the constitution on the basis of the post-war system, prompt the SDF to become an army that can participate in collective security operations.

The popular American finance website disclosed on March 26 that on 22, the Finance Minister of Japan, Aso Taro, had a discussion with the famous economist Paul. R. Krugman's. Abe was also there. Aso Taro mentioned that the economic situation of Japan at recent years, was equal of the economic crisis era of the 1930 s in the US.

\footnotetext{
${ }^{24}$ Liu Jiangyong, "The Skeleton of Abe Shinzo's Politics and Ideology”, Asia \& Africa Review, 2006, vol. 5, pp. 30-36.

${ }^{25}$ Liu Jiangyong, "The Skeleton of Abe Shinzo's Politics and Ideology", Asia \& Africa Review, 2006, vol. 5, pp. 30-36.

${ }^{26}$ Nakanishi, Hiroshi, "Military Cooperation and Territorial Disputes: The Changing Face of Japan's Security Policy". In Japan:

The Precarious Future, edited by Frank Baldwin and Anne Allison. New York: New York University Press, 2015, p. 236.

${ }_{27}$ Heisei 17, Defense White Paper, http://www.clearing.mod.go.jp/hakusho_data/2005/2005/index.html.

${ }^{28}$ Heisei 19, Defense White Paper, I(2), http://www.clearing.mod.go.jp/hakusho_data/2007/2007/index.html.

29 Heisei 22, Defense White Paper, I(3), http://www.clearing.mod.go.jp/hakusho_data/2010/2010/index.html.

${ }_{30}$ Heisei 24, Defense White Paper, II(2), http://www.clearing.mod.go.jp/hakusho_data/2012/2012/index.html.

31 Zhang Hua, "Political philosophy of Abe in two terms", Journal of Mudanjiang University, 2014, Jan. vol. 23, pp. 141-143.
} 
"What solved the question? War!" Because the United States relied on World War II in the 1940s to out of the economic crisis. "We" are looking for the "trigger" ${ }^{32}$ Of course, this is not to say that Japan has prepared for War. But the bottoming out of Japanese economy, really need a starting point. Aso Taro implied that wars giving rise to a large number of investment opportunities.

In March 2016, the macro statistics of Japan show that Japanese machinery orders deviated almost twice from the expected highest standard and rose up to the biggest gain since January 2003 . That is, surged $15 \%$. For this kind of "indistinct movement" of heavy industries, Chinese experts predicted that "it is very likely that the military investment is on the rise". 33

Although the dialog of Aso Taro with Paul Krugman eventually said that "Japan is looking for a way just to approach to the Second World War, but not war", this is obviously a contradictory rhetoric. From the ambitions of Japan in East Asia, Japan'soverstating of threat of China, and Japanese officials' hope of recovering Japanese economy bya way that "similar to the method of the second world war", "there are reasons for Japan to hope that East Asia or Northeast Asia will face war again". 34

\section{Conclusion}

The needs and ambition of Japan to East Asia decided that Japan did and would have the similar behavior in East Asia. When economic method is to be of benefit to Japan, it will use mild policy to the mainland. However, if Japan cannot be the leader and feel threat, it will turn to hard even military strategy. Historically, there werethe Financial Mainland Policy and the Mild Mainland Policy, and it finally turned to the Hard Mainland Policy even the war. That is the reason for East Asia to maintain vigilance to Abe's international strategy and revision of constitution today.

\section{References}

Heisei 17, Defense White Paper, http://www.clearing.mod.go.jp/hakusho_data/2005/2005/index.html Heisei 19, Defense White Paper, I(2), http://www.clearing.mod.go.jp/hakusho_data/2007/2007/index.html Heisei 22, Defense White Paper, I(3), http://www.clearing.mod.go.jp/hakusho_data/2010/2010/index.html Heisei 24, Defense White Paper, II(2), http://www.clearing.mod.go.jp/hakusho_data/2012/2012/index.html Huang, D. T. (2006). On Japan's continental policy and Russia's Far East Policy. Northeast Asia Forum, 14(4), 85-89.

Ishii, K., \& Huang, S. H. (trans.). (2008). Economic History of Japan. Taibei: Wu-Nan Book Company Ltd.

Johnstone, C. B. (1999). Paradigms lost: Japan's Asia policy in a time of growing Chinese power. Contemporary Southeast Asia, 21(3), 365-385.

Japanese Ministry of Foreign Affairs. (1966). Japan's Foreign Chronology and Primary Documents. Tokyo: Hara Shobo.

Jiang, X. Z. (1985). "China and the Washington Conference", Series Editor Committee of Sino-US Relations. Proceedings of Sino-American Relations (First Series). Chongqing: Chongqing Publishing House.

Lei, S. H. http://leisihai.blog.ifeng.com/article/44378148.html

Li, L. Y. (1999). Invasion and annexation of Ryukyu modern formation of Japan's continental policy. Fuyang College Journals, 4 , 97-103.

Li, Q. (2007). Japan's China policy at the beginning of the 21 st century and its impact on Sino-Japan relations. Journal of Binzhou Vocational College, 4, 13-17.

Liu, J. Y. (2006). The skeleton of Abe Shinzo's politics and ideology. Asia \& Africa Review, 5. 30-36.

Liu, Y. H. (2015). The Manchuria political stability and diplomatic in Shidehara period. Journal of Foreign Study, 4, 37-41.

32 Zerohedge, Japan's Finance Minister Accidentally Reveals How It All Ends: “War". http://www.zerohedge.com/news/2016-03-26/japans-finance-minister-accidentally-reveals-how-it-all-ends-war.

33 Lei Sihai, http://leisihai.blog.ifeng.com/article/44378148.html.

34 Lei Sihai, http://leisihai.blog.ifeng.com/article/44378148.html. 
Lv, P. (2014). The separation between Japanese economic policy and political policy to China under the trilateral structure of PRC-USA-Japan. Journal of Liaoning University, 42, 172-177.

Ma, L. (2001). US-Japan peace and conflict under the system of Washington. Journal of Hubei University of Education, 28, 65-67.

Nakanishi, H. (2015). Military cooperation and territorial disputes: The changing face of Japan's security policy. In F. Baldwin and A. Allison (Eds.), Japan: The precarious future. New York: New York University Press.

Oohata, T. (1993). Diplomatic history of Japan. Tokyo: Seibundoh.

Xiong, P. B. (2005). Modern Japanese hegemony strategy. Beijing: Social Sciences Press.

Zang, Y. K. (2006). Modern Sino-Japanese war and Japan's China policy Beijing. Beijing: Publication of Social Science.

Zerohedge. Japan's Finance Minister accidentally reveals how it all ends: “War”. Retrieved from $\mathrm{http}$ ://www.zerohedge.com/news/2016-03-26/japans-finance-minister-accidentally-reveals-how-it-all-ends-war

Zhang, H. (2014). Political philosophy of Abe in two terms. Journal of Mudanjiang University, 23, 141-143. 